\title{
Refinancing Risk and Disclosure of Corporate Investment
}

August 30, 2018

\begin{abstract}
This paper investigates the relation between the refinancing risk of corporate debt and firms' decisions to issue capital expenditure forecast. Building on theories of financing frictions that predict a negative relation between refinancing risk and firm investment and theories of strate-gic voluntary disclosure where managers can withhold the unfavorable news of reduced invest-ment, we find that an increase in refinancing risk is associated with both lower probability of disclosing capital expenditure forecasts and lower frequency of capital expenditure forecasts. Cross-sectional tests show that firms that are more exposed to refinancing risk and are less able to mitigate refinancing risk are more likely to reduce capital expenditure forecasts following an increase in refinancing risk. Our results suggest that capital structure can influence firm information environment through managers' disclosure incentives.
\end{abstract}




\section{Introduction}

How does debt financing affect firm disclosure? It is commonly believed that debt financing has a limited effect. This is because debt is, by construction, less sensitive to information than equity, which implies a lower demand for information from debtholders. More importantly, lenders can privately communicate with borrowers. These two reasons indicate a muted lender demand for public disclosure from borrowers. However, recent studies suggest that although lenders' demand for information itself may not affect firm's information environments, lenders' economic activities may do so. For example, Kim et al. (2018) show that a decrease in lenders' monitoring increases shareholders' demand for information and borrowers' disclosures. Adding to these recent studies, we examine corporate disclosure incentives when firms seek debt refinancing. Specifically, we predict and demonstrate that firms facing high refinancing risk reduce their disclosures to mask bad news regarding corporate investment from shareholders.

Firms face refinancing risk when seeking debt refinancing. Refinancing risk is the risk of failure to refinance the principal repayment that becomes due. ${ }^{1}$ Materialization of refinancing risk means that firms need to repay the principal, which is typically a large amount relative to interest payments. Studies show that losing a large amount of cash can prevent management from pursuing investment opportunities (Rauh, 2006; Almeida et al., 2012), which shareholders interpret as bad news (Lummer and McConnell, 1989). Because management has incentives to withhold bad news from shareholders (e.g., Houston et al., 2010; Chen et al., 2011), we hypothesize that management decreases disclosures during periods of high refinancing risk. Unlike prior studies that mainly focus on earnings forecasts, we predict that refinancing risk is associated with fewer disclosures of capital expenditure forecasts because refinancing risk directly affects whether investment opportunities are pursued.

Our prediction assumes that management who has bad news about investment can withhold it from shareholders. Grossman (1981) and Milgrom (1981) independently show that if nondisclosure is interpreted by investors as the worst news, management will disclose all news. Such unraveling does not occur, that is, shareholders do not interpret nondisclosure as the worst news for several reasons. First, higher refinancing risk, by its definition, is associated with heightened

\footnotetext{
${ }^{1}$ Prior literature also refers to this risk as liquidity risk (Diamond, 1991) and rollover risk (He and Xiong, 2012).
} 
uncertainty about the likelihood of refinancing. Non-disclosure can occur because management has no information about the refinancing outcome instead of management having the worst news. Second, management may choose not to disclose capital expenditure forecasts because no investment plans have been made. This possibility reflects the fact that capital expenditures can be irregular. Finally, interpreting nondisclosure is not as straightforward as interpreting disclosures, which requires that investors understand management's strategic disclosure incentives and infer the private information based on the action of nondisclosure. Studies demonstrate that economic agents do not exhibit such strategic thinking and therefore do not fully react to the implications of nondisclosures. Nondisclosure is also less salient than disclosures, which reduces the likelihood of investors paying attention to nondisclosure and reacting to its implication. The combination of these forces suggests that shareholders do not interpret nondisclosure as the worst news.

Firms that seek refinancing have incentives to signal firm quality. An alternative hypothesis is therefore that firms increase capital expenditure forecasts when refinancing risk is high. Frankel et al. (1995) show that firms that seek external capital tend to increase disclosures. Lang and Lundholm (2000) find that firms alter their information environment in the period prior to equity issuance. Although firms in our sample tend to seek financing from banks, which can privately communicate with firms, the possibility remains that firms can use public disclosures to increase the credibility of its private communication with lenders.

We measure firms' exposure to refinancing risk using the percentage of long-term debt due for repayment in the next year, which follows the literature of corporate debt maturity structure and refinancing risk (e.g., Barclay and Smith, 1995; Harford et al., 2014). The idea is that a higher percentage of long term debt due in the next year implies a larger amount of financing needed to be raised, and by extension, a higher refinancing risk. ${ }^{2}$

Our sample starts with firms that can be matched to the I/B/E/S Guidance data and therefore issue at least one management forecast within the sample period of 2003-2016. We keep firm-years

\footnotetext{
${ }^{2}$ We follow Harford et al. (2014) and do not use short term debt because short term debt such as working capital and accounts payable is mainly used to finance short term operations as opposed to investment opportunities and hence is not the focus of this paper. This approach is similar to the one taken by Almeida et al. (2012) and Gopalan et al. (2014) and is predicated on the basis that long-term debt due within the next year is based on debt maturity decisions made by the firm several years prior, which is unlikely to be correlated with investment opportunities in the next year. Using short-term debt raises another concern that changes in firm credit quality and short-term debt are correlated, as predicted by Diamond (1991). Because underlying changes in firm credit quality affect the use of short-term debt as well as firms' disclosure decisions, examining short-term debt precludes us from studying how the presence of debt itself affects disclosure incentives.
} 
that have total debt larger than $10 \%$ of total assets, because a firm with extremely low leverage is unlikely to be affected by refinancing risk and hence is not the focus of this study. To ensure that capital expenditure is an important aspect of firm information environment, we exclude firms in service industries, for which capital expenditure is not the main driver of their business model. We also exclude financial service and utility industries following prior studies.

We find that firms with higher refinancing risk have lower likelihood and frequency of capital expenditure forecasts. Other things equal, an inter-quartile increase in refinancing risk is associated with 2.25 percentage points lower likelihood of issuing capital expenditure forecasts in a year, and a decline in the number of capital expenditure forecasts by 1.2. The finding is consistent with management withholding news about the negative consequence of refinancing risk on corporate investment. The finding is inconsistent with the competing hypothesis that firms increase public disclosure to mitigate refinancing risk.

We conduct two validation tests to ensure that our main empirical findings are consistent with management withholding bad news about investment. First, our measure, the percentage of longterm debt due within the next year, captures refinancing risk. In theory, higher refinancing risk is associated a higher likelihood of failure to obtain financing. Periods of refinancing risk should be associated with less investment. The empirical evidence is consistent with this prediction. Second, because we hypothesis that management reduces disclosures to hide bad news when refinancing risk is high, a non-disclosure of capital expenditure forecasts is on average associated with worse news than disclosures. Directly measuring bad news about investment using the level of investment is difficult. We instead show that when refinancing risk is high, nondisclosure of capital expenditure forecasts is associated with worse market reaction than disclosures of capital expenditure forecasts. The finding is consistent with management choosing to disclose more favorable news and withhold worse news.

To mitigate endogeneity concerns, we control for factors that prior studies show to affect firms' maturity choices because these factors are correlated with the percentage of long-term debt due in the next year, our measure of refinancing risk. For example, a larger amount of debt due in the next year might indicate either deleveraging efforts by firms with sufficiently good performance or failure of refinancing in the current year. Both could affect disclosure decisions. We also include general controls for factors that affect disclosure decisions. After controlling for firm and year fixed effects 
and the control variables mentioned above, variation in the amount of debt due in the following year is mainly driven by firms' financing decisions made several years in the past, which makes it less likely to directly affect disclosure decisions of the following year.

To further demonstrate that our findings are driven by refinancing risk, we explore crosssectional variation in firms' exposure to refinancing risk and their capability of mitigating refinancing risk. First, if refinancing risk drives our results, firms with a higher exposure to refinancing risk should be more likely to reduce the disclosure of capital expenditure forecasts because, according to our prediction, these firms are more likely to fail to obtain financing and have bad news about their investments. We measure firms' exposure to refinancing risk with three proxies: the level of firm leverage, ex-ante uncertainty, and credit rating. Studies find that higher leverage is negatively associated with firm growth, suggesting that higher leverage reduces lenders' willingness to supply credit (e.g., Lang et al., 1996). Similarly, higher uncertainty and a lower credit rating also reduce lenders' willingness to supply credits, which subject borrowers to higher refinancing risk (e.g., Stiglitz and Weiss, 1981). We find that other things equal, an inter-quartile increase in refinancing risk for firms with higher exposures to refinancing risk is associated with 1.4, 1.7, and 1.4 fewer capital expenditure forecasts than firms with lower exposures to refinancing risk, when exposures to refinancing risk are measured with ex-ante uncertainty, speculative grade ratings, and high leverage, respectively.

Second, we expect that firms that have less capability of mitigating refinancing risk are more likely to reduce the disclosure of capital expenditure forecasts. We follow Harford et al. (2014) and measure firms' capability of mitigating refinancing risk with cash holdings. The idea is that firms with higher cash holdings can mitigate refinancing risk by using internal cash to finance their projects. Similarly, we expect that firms with higher profitability can use proceeds from their existing projects to satisfy their need for additional investment. We find that the relation between refinancing risk and capital expenditure forecasts is mitigated for firms with higher cash holdings and higher profitability. In our sample, firms with lower profitability reduce the number of capital expenditure forecasts by 2 , all else equal, for an inter-quartile increase in refinancing risk compared to 1 during periods of high profitability. Similarly, firms with higher cash holdings reduce the number of capital expenditure forecasts by .8 compared to a reduction of 1.85 during periods of low cash holdings. 
An alternative mechanism that explains our findings is lender monitoring. Gul and Goodwin (2010) document that short term debt is associated with increased monitoring. Kim et al. (2018) show that reduced lender monitoring due to CDS trading increases shareholders' demand for information. Combining the findings of these two studies predicts a negative relation between refinancing risk (higher monitoring) and capital expenditure forecasts.

We test the monitoring mechanism in two ways. First, we rely on the findings of Kim et al. (2018) that lender monitoring is a substitute for shareholder monitoring, which predicts a reduction in all voluntary disclosure, not simply capital expenditure forecasts. We do not find a negative association in earnings forecasts, suggesting that lender monitoring is not the primary economic forces at play during periods of refinancing risk. The likely reason is that although bad news regarding investment may also mean bad news regarding future earnings, it is unclear at what point in the future the bad news would map into earnings. The timing of this would be a function of the horizon of the investment itself. As a result, the materialization of refinancing risk affects current-year earnings less than investment, and by extension, earnings forecasts less than capital expenditure forecasts. Second, if lender monitoring explains our effect, we expect our results to vary based on the level of shareholder monitoring, measured with the percentage of institutional ownership. We do not find that our results depend on shareholder monitoring. Therefore, lender monitoring does not seem to explain the effect of refinancing risk.

Our paper adds to the growing literature that examines the disclosure incentives in debt markets. Prior studies examine the effect of information environment on debt financing (e.g., Sengupta, 1998). We examine the reverse and show that refinancing risk can affect firm information environment. Although lenders may not themselves demand public disclosures because they can privately communicate with firms, recent studies show that debt financing affects public disclosures through lenders' interactions with borrowers or borrowers signalling their type. For example, Lo (2014) finds that U.S. borrowers from banks with high exposure to the emerging markets crisis increased their propensity to issue management forecasts compared to other borrowers. He attributes this increase to borrowers mitigating future switching costs in the event the borrower must seek other sources of financing. Vashishtha (2014) finds that management forecast issuance declines following the transfer of control rights to the lender upon a covenant violation. Chen and Vashishtha (2017) find that firms disclosure more following bank mergers because mergers increase bank size and 
large banks rely more on hard information to monitor borrowers. Kim et al. (2018) document that reduced lender monitoring due to the CDS trading increases shareholders' demand for information, which in turn increases disclosures. We add to the literature by showing that refinancing risk can affect the disclosure of capital expenditure forecasts through its effects on firm investment and managers' incentive to withhold bad news about investments.

Our paper also contributes to the voluntary disclosure literature by examining capital expenditure forecasts. Capital expenditure forecasts are economically important but are not wellunderstood. Although a large number of studies examine management forecasts and in particular earnings related forecasts, studies that examine other forms of voluntary disclosure remain limited (Hirst et al., 2008; Beyer et al., 2010). Han and Wild (1991) examine market reactions to both revenue and earnings forecasts. Hutton et al. (2003) examine firms' decision to supplement management forecasts with additional explanatory languages to add credibility. Wasley and Wu (2006) examine firms' decision to issue cash flow forecasts and argue that these forecasts are used as a signaling device for better performance as well as a commitment device for lower levels of earnings management. Among studies that examine capital expenditure forecasts, Lu and Tucker (2012) find that some firms provide more capital expenditure forecasts in response to earnings decline, suggesting a substitution role between earnings and capital expenditure forecasts. Bae et al. (2017) show that managers learn from analyst feedback when providing capital expenditure forecasts, which enhances capital investment efficiency. Ali et al. (2018) find that capital expenditure forecasts can mitigate the agency conflicts between lenders and borrowers because the forecasts have commitment value. We differ from these studies by examining refinancing risk as a potential driver of capital expenditure forecasts. Our finding that refinancing risk affects the disclosure of capital expenditure forecasts adds to the literature on other forms of forecasts. We show that refinancing risk explains capital expenditure forecast decisions but not earnings forecast decisions. The result suggests that the same factor that affects one type of disclosure need not drive another type.

We finally contribute to the literature on refinancing risk. Many studies posit the role of refinancing risk in influencing firm decisions. Diamond (1991) posit that refinancing risk plays a central role in shaping firms' debt maturity decision. Morris and Shin (2009) show that refinancing risk increases the probability of a run on the firm, and He and Xiong (2012) find that refinancing risk increases conflict of interest between creditors and shareholders. Furthermore, Harford et al. 
(2014) find that firms increase their cash holdings in order to mitigate refinancing risk. We find that refinancing risk can also affect firm information environment.

The remainder of this paper is organized as follows. In Section (2), we develop my hypotheses; in Section (3), we discuss data sources, the sample selection, and construction of key variables. In Section (4), we outline our research design; in Section (5), we present descriptive statistics and empirical findings. We conclude in Section (6).

\section{Hypothesis Development}

Our main prediction is that firms facing heightened refinancing risk reduce their disclosures of capital expenditure forecasts. The prediction follows two steps. First, refinancing risk increases the likelihood of bad news about firm investments. Following Harford et al. (2014), we define refinancing risk as the risk that firms cannot obtain external financing to repay the principal that becomes due, or obtain financing with unfavorable terms. Refinancing risk arises because of capital market frictions. Specifically, lenders can refuse to provide credit due to asymmetric information (Stiglitz and Weiss, 1981) or borrowers' moral hazard problems which require ex-post costly monitoring (Williamson, 1987). Even when refinancing occurs, the terms of refinancing can be adverse for

borrowers. For example, lenders can charge a higher interest rate (e.g., Froot et al., 1993). In the event that refinancing risk materializes, a capital constrained firm is forced to forgo valuable investment opportunities (Rauh, 2006), which shareholders interpret as bad news (Lummer and McConnell, 1989).

Second, managers have incentives to withhold bad news about investment. Theories of discretionary disclosures show that managers can strategically withhold bad news in the presence of disclosure frictions (e.g., Verrecchia, 1983; Dye, 1985; Jung and Kwon, 1988). Empirical studies support this prediction by showing managers are more likely to reduce the disclosures of earnings forecasts when news about firm performance is bad (e.g., Chen et al., 2011; Houston et al., 2010). We extend the logic of strategic bad news withholding to the decision to disclose capital expenditure forecasts. We argue that management has incentives to withhold bad news about investment that arises from refinancing risk, for fear that disclosing the information leads to negative capital market consequence. We summarize the prediction as follows. 
H1: Refinancing risk is negatively associated with the likelihood and frequency of capital expenditure forecasts.

Note that in H1, shareholders might perfectly observe changes in refinancing risk. But without managers' disclosures about investments, they remain uncertain about how management responds to refinancing risk, whether firms successfully obtain refinancing and, if so, whether the financing proceeds are used to invest.

Besides the information asymmetry between investors and managers, withholding news is possible for several frictions related to the nature of capital expenditure forecasts. First, capital expenditures can be proprietary. ${ }^{3}$ For example, firms might withhold information about investment because a disclosure informs competitors about their future production plans. Investors cannot differentiate whether withholding is because of proprietary cost or bad news about investment. Second, the period of refinancing risk is associated with heightened uncertainty about the likelihood of obtaining financing and the terms of financing, which in turn increases uncertainty about future investment. This uncertainty allows firms that fail to obtain financing to pool with firms that haven't yet obtained financing, which in turn makes withholding news possible. Finally, interpreting nondisclosure is not as straightforward as interpreting disclosures. Interpreting nondisclosure requires that investors understand management's strategic disclosure incentives and infer the private information based on the action of nondisclosure. Economic agents do not exhibit such strategic thinking and therefore do not fully react to the implications of nondisclosures. Investors are less likely to paying attention to nondisclosure and reacting to its implication because nondisclosure is less salient. The combination of these forces suggests that shareholders do not interpret nondisclosure as the worst news.

Although our prediction applies to both the likelihood and frequency of capital expenditure forecasts in theory, stopping providing forecasts can be more difficult than reducing the frequency of capital expenditure forecasts, particularly when there is strong capital market demand for the information. As a result, firms may not stop providing capital expenditure forecasts but simply

\footnotetext{
${ }^{3}$ Consistent with this proprietary nature, while many firms have capital expenditures, many do not issue capital expenditure forecasts.
} 
reduce the frequency of these forecasts. Hence, in our empirical tests we examine both frequency and probability of capital expenditure forecasts.

Besides the investment channel posited in $\mathrm{H} 1$, in theory, a relation between refinancing risk and capital expenditure forecasts can be driven by two alternative mechanisms. First, periods of high refinancing risk is associated with heightened lender monitoring. For example, Gul and Goodwin (2010) find that lenders increase their scrutiny over managerial actions during periods of credit rollover. Prior studies document that monitoring can affect corporate disclosure decisions but provide mixed evidence on the sign of the relation. On the one hand, to the extent that lender monitoring improves corporate governance, studies find that firms voluntarily disclose more information (Ajinkya et al., 2005). On the other hand, Kim et al. (2018) find that firms provide more earnings forecasts when lender monitoring decreases, proxied by CDS trading, which suggests a negative relation between refinancing risk and disclosures.

To investigate the monitoring mechanism, we examine the effects of refinancing risk on the provision of current-year earnings forecasts. Despite documenting different signs for the relation between monitoring and disclosures, the consensus from prior studies is that monitoring affects the provision of earnings forecasts. In contrast, the investment channel laid out in H1 mainly applies to capital expenditure forecasts, and less likely to current-year earnings forecasts. Although materialization of refinancing risk has negative effects on investments, the effects manifest in earnings with delays, which vary as a function of the investment horizon. To put it differently, current-year earnings is also affected by investments made in the past and contracts already signed with customers. As a result, the investment channel predicts a smaller response of earnings forecasts to refinancing risk than that of capital expenditure forecasts. Furthermore, if management has incentives to camouflage the negative effects of refinancing risk on investment, they may even increase earnings forecasts so that investors pay less attention to the bad news from refinancing risk. We examine the effect of refinancing risk on earnings forecasts to differentiate the monitoring channel.

In addition to examining earnings forecasts, we use cross-sectional variation in shareholder monitoring to validate the monitoring channel. The idea is that if higher refinancing risk changes firm disclosures through changes in monitoring, the existing level of monitoring from shareholders should affect the changes in disclosures.

The second alternative mechanism is that firms looking to mitigate refinancing risk can look 
to public financing, which motivate them to improve the information environment. For example, Frankel et al. (1995) show that firms increase disclosure prior to equity financing. Sengupta (1998) finds that higher public disclosure quality is associated with lower corporate bond yield. If firms facing refinancing risk turn to the equity or public bond market for financing, they will increase their disclosures. We argue that the channel is unlikely to manifest in our case because firms that facing refinancing risk continues to use debt, which allows them to private communicate with lenders. Nevertheless, the possibility remains that firms can increase their public disclosures to increase the credibility of their communications with lenders. An increase in disclosures is the opposite to what $\mathrm{H} 1$ predicts. Because the signs of the empirical predictions differ, finding a negative relation between refinancing risk and disclosures is inconsistent with this alternative mechanism

We further substantiate our main prediction by exploring two cross-sectional variations of refinancing risk. First, we expect that, if refinancing risk drives disclosure decisions, the negative relation between refinancing risk and the disclosure of capital expenditure forecasts should strengthen for firms with higher exposures to refinancing risk. The reason is that when firms are more exposed to refinancing risk, an increase in refinancing risk results in a more negative effect on investments, which reduces managers' incentives to provide capital expenditure forecasts.

Our second set of tests examine firms that are less able to mitigate refinancing risk. The negative effects of refinancing risk on investments of these firms are larger. According to H1, these firms are more likely to reduce the disclosure of capital expenditure forecasts. We formalize these cross-sectional predictions in the following hypotheses:

H2a: The relation between refinancing risk and the likelihood of capital expenditure forecasts is stronger for firms that are more exposed to refinancing risk.

H2b: The relation between refinancing risk and the likelihood of capital expenditure forecasts is stronger for firms that have less capability to mitigate refinancing risk. 


\section{Sample Selection}

We collect all management forecasts from I/B/E/S Guidance. We limit the sample between 2003, the year I/B/E/S guidance started collecting management forecast data, and 2016. We then match management forecast data with Compustat. To measure forecast practice, we drop forecasts that occur after their corresponding fiscal year end dates, because these are more likely to be preannouncement of earnings (Anilowski et al., 2007). We then assign forecasts into firm fiscal years according to their corresponding forecast announcement dates, and create measures of both the existence and frequency of capital expenditure forecasts. We also collect earnings related forecasts for falsification tests. By using the merged sample between I/B/E/S Guidance and Compustat, we effectively delete firms that never provide management forecasts. Our empirical prediction does not apply to firms that never forecasts. That is, we do not expect refinancing risk to be the reason why these firms never issue any management forecasts, unless these firms are in the state of constant suffering of refinancing risk. The sample selection choice defines the population we are interested in to be those firms that have forecasting practice and can potentially reduce forecasts when experiencing heightened refinancing risk.

Following prior studies, we then drop firms from finance and utility industries (two-digit SIC codes of 49 or 60-67). We also drop firms from the service industries. The capital expenditure of these firms is not the primary driver of their business model. Therefore we do not expect that they mainly use capital expenditure forecasts to convey value relevant information. Finally, we drop firm-year observations where total leverage was less than 10 percent of total firm value. Firms with low leverage rely less on debt and by definition do not face substantial refinancing risk. These firms are not the focus of this study.

For our regression analysis, we require non-missing control variables. Most control variables are obtained from Compustat. Variables that use stock price and returns are from CRSP. Number of analyst following is from I/B/E/S Detail History. The percentage of institutional ownership is from Thomson Reuter. The sample section procedure in the end yields a final sample of 17,188 firm-years with non-missing control variables from the years 2003-2016. 


\section{Research Design}

\subsection{Main test}

We test our main prediction from $\mathrm{H} 1$ by examining the association between refinancing risk and capital expenditure forecasts, controlling for known determinants that jointly affect these two constructs. Our regression model is

$$
\text { CAPX Guide }_{i t+1}=\beta_{0}+\beta_{1} \text { RefRisk }_{i t}+\beta_{2} X_{i t}+\epsilon_{i t},
$$

where $C A P X$ Guide $_{i t+1}$ is the existence and frequency of capital expenditure forecasts of firm $i$ in year $t+1, R e f R i s k_{i t}$ is the refinancing risk of firm $i$ at the end of year $t$, measured with long term debt due in year $t+1$ as a percentage of total debt outstanding at the end of year $t$, and $X_{i t}$ represents a vector of control variables to be discussed below.

Following prior studies, we do not use short-term debt to measure refinancing risk for two reasons. First, as argued by Harford et al. (2014), the amount of long-term debt due better captures the risk of financing firms' long-term investment. In contrast, short-term debt is generally issued to finance short-term assets for day-to-day operations instead of long-term investment. It is paid down within the year and is usually not refinanced. Second, as shown by Diamond (1991), firms of both low and high credit quality choose short-term debts. The relation between firms' credit quality and the usage of short-term debts aggravates the endogeneity problem because shocks to firms' credit quality are also likely to be related to their disclosure decisions.

In contrast with using short-term debt, using the amount of long-term debt due in the next year has identification benefits. By definition, the amount of long-term debt is determined several years ago. Conditional on determinants of current-year maturity choices and firm and year fixed effects, variation in the percentage of long-term debt due in the next year is less likely to be correlated with firms' current economic conditions, which makes the measure less endogenous to disclosure decisions of the next year than short-term debt.

Despite our argument for the measure's identification benefit, the endogeneity concern remains that the measure is not randomly assigned. In particular, anticipating a higher amount of debt in the next year, firms may change their financing decisions in the current year. For example, a larger 
percentage of debt due in the next year might reflect firms' decision to change maturity (Barclay and Smith, 1995) or dynamically adjust maturity $(\mathrm{Xu}, 2017)$. This could in turn affect disclosure decisions in the next year. To alleviate the concern that refinancing risk is endogeneous to firms' maturity choice and disclosure decisions, we control for factors that affect both the percentage of long-term debt due in the following year, our measure of refinancing risk, and firms' decisions to issue capital expenditure forecasts. Among variables that affect disclosure decisions, we only include variables that we expect to be correlated with firms' decisions to issue capital expenditure forecasts. We also include firm and year fixed effects to control for across-firm and across-year heterogeneity.

Our choice of control variables relies on the large literature on firms' debt maturity and disclosure decisions. When describing the control variables below, we also discuss the literature on firms' maturity choice to ensure that we include control variables that are relevant to our purpose.

\section{Leverage}

Leverage is an important determinant of firm maturity. Billett et al. (2007) find a strong positive relation between leverage and maturity other things equal. The relation between leverage and firm capital expenditure forecasts is less clear. Lu and Tucker (2012) do not include it as the determinant. Guay et al. (2016) include leverage as a control when examining firms' decision to issue management forecasts. Leverage loads positively in fixed effects specification while negative in the specification without fixed effects. There is also no clear theoretical prediction relating leverage and disclosure except that leverage may be associated with firm growth opportunity (Barclay and Smith, 1995).

2. Book-to-market ratio (BTM).

We use book-to-market ratio to capture firms' investment opportunities in year $t$. Barclay and Smith (1995) find that firms with more investment opportunities, that is, lower book-tomarket ratio, are less likely to use long-term debt. Billett et al. (2007) find similar results by simultaneously examining leverage, maturity, and covenant. In the disclosure literature, book-to-market ratio is often used to capture proprietary costs, since firms with higher growth opportunities are more likely to have proprietary information. Ajinkya et al. (2005) find no relation between proprietary costs, proxied by market-to-book ratio, and a firms forecast 
decisions. Ajinkya et al. (2005) examine earnings forecasts, which may have lower levels of proprietary costs than capital expenditure forecasts. In addition, firms with higher growth opportunity have higher external financing needs, which increases the incentive to disclose. For example, Frankel et al. (1995) find that firms that seek external financing are more likely to increase disclosure.

\section{Firm size.}

We use log market value of equity at the end of year $t$ to capture firm size. Size has been an important control variable for almost all disclosure studies, which is used to proxy for general demand for information and firm visibility. Size is also an important determinant of firm maturity structure, as shown by Barclay and Smith (1995) and Billett et al. (2007). Furthermore, prior literature has found that size, which is inversely related to information asymmetry, is likely to have shorter-term debt in the form of bank loans and hence may be more subject to refinancing risk; firms with a high information asymmetry are also more likely to benefit from improving the information environment to mitigate information uncertainty.

\section{Firm performance.}

Firm performance is used to capture the observed firm credit quality. Theories on maturity structure provide mixed predictions on the relation between firm credit quality and maturity structure (e.g., Diamond, 1991, 1993; Rajan, 1992). Empirical research typically finds a positive relation between maturity and firm performance. Firm performance is positively associated with the likelihood of issuing management forecasts (e.g., Houston et al., 2010; Chen et al., 2011). However, the relation between performance and capital expenditure forecasts is less clear because firms may have incentive to use capital expenditure forecasts to mitigate the negative impact of earnings forecasts that convey bad news. Lu and Tucker (2012) do not find a significant relation between firm performance and the likelihood of issuing capital expenditure forecasts. Their sample is only based on a single year (2005), so power might be an issue. Following Chen et al. (2011), we use capture firm performance using annual stock return adjusted by market return. We also include return on assets to be consistent with the maturity structure literature. Following Houston et al. (2010), we also add an indicator for loss in year $t$. 


\section{Return volatility.}

We use return volatility to capture uncertainty about firms' future cash flow. Although Barclay and Smith (1995) do not include it as a determinant of maturity structure, Billett et al. (2007) find a positive relation between cash flow volatility and maturity. To create a measure that is less dependent on firm time series, we follow the disclosure literature and control for firm daily return volatility in year $t$, which captures firms' information environment (Nagar et al., 2003; Chen et al., 2011).

6. The percentage of institutional ownership and the number of analyst following.

There is no direct relation between institutional ownership and maturity structure. The percentage of institutional ownership is often used as a control variable for management forecasts (e.g. Healy et al., 1999; Bushee and Noe, 2000; Ajinkya et al., 2005). In the same spirit, we also control for the natural logarithm of analyst following.

7. Long term debt issuance.

$\mathrm{Xu}$ (2017) shows that firms dynamically adjust their maturity structure after issuance. We use the amount of long-term debt issuance in year $t$ scaled by the total debt in year $t-1$ to capture the extent to which firms adjust maturity. To the extent that our existing control variables (including firm fixed effects) do not capture all factors that determine firms' maturity structure, the amount of long-term debt issuance should capture the additional unobserved factors.

Throughout all our analyses, we cluster standard errors by firm. In addition, we estimate OLS regressions using the decile ranks of the independent variables scaled from 0 to 1. Similar to Guay et al. (2016), doing so allows for a meaningful comparison of the economic significance between the independent variables. Hence, the coefficient of our variable of interest, the interaction, measures how voluntary disclosure of capital expenditure forecasts changes when moving from the bottom to top decile of refinancing risk. 


\subsection{Cross-sectional tests}

We test our cross-sectional predictions by modifying equation (1) to include the interaction term between RefRisk $k_{i t}$ and cross-sectional indicators:

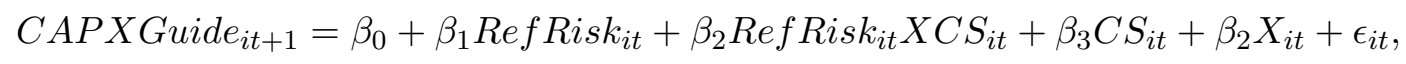

where all variables are defined as before and $C S_{i t}$ is the cross-sectional indicators.

The coefficient of interest is $\beta_{2}$, which captures the differential effect of refinancing risk when the cross-sectional variable takes one. From H2 in section 2, the negative association between refinancing risk and capital expenditure forecasts is stronger when firms are more exposed to refinancing risk and firms' capability to mitigate refinancing risk is low.

We measure firms' exposures to refinancing risk with three proxies. The first proxy is firm leverage. Highly levered firms are more exposed to refinancing risk, because firms with higher leverage need to refinance a larger amount of debt for the same percentage of debt due in the next year, and refinancing a large amount of debt is presumably more difficult, other things equal. Furthermore, firms with a higher level of leverage have higher credit risk and may face higher credit rationing from lenders. Consistent with the negative consequence of high leverage, Opler and Titman (1994) find that firms with a higher leverage lose substantial market share to competitors during industry downturns. We define a firm-year observation to have high leverage if leverage is larger than the $75^{\text {th }}$ percentile of its full-sample distribution. The second proxy is the level of ex-ante uncertainty. Lenders are more likely to ration credits when information asymmetry is high (Stiglitz and Weiss, 1981). We expect that higher ex-ante uncertainty increases firms' exposure to refinancing risk. We define a firm-year to have high ex-ante uncertainty if return volatility is larger than its cross-sectional median. The third proxy is credit quality. For the same amount of debt due in the next year, lenders are more likely to ration credit if the credit quality of the borrower is low. We define low credit quality if a firm's credit rating is speculative grade.

We measure firms' capability of mitigating refinancing risk with two proxies. First, firms with a higher portion of cash holdings relative to total debt face less refinancing risk to finance their investments as they are able to do so internally. Consistent with this idea, Harford et al. (2014) conclude that firms build up cash reserves in order to mitigate refinancing risk. We define a firm- 
year to have high cash-holdings if cash-holdings are larger than the $25^{\text {th }}$ percentile of its full-sample distribution. As a second proxy, we argue that firms that have performed well in the prior year face less refinancing risk as better performance indicates lower default risk and higher ability to service debt payments. We define a firm-year to have better performance if its ROA is higher than its full-sample median.

Our proxies for the exposure to refinancing risk and firms' ability to mitigate refinancing risk are not mutually exclusive. For example, a firm with high leverage presumably also has difficulty mitigating refinancing risk. The purpose of the cross-sectional tests is not to pin down the mechanism. Rather, they serve to validate our main hypothesis that refinancing risk is associated with reduced incentive to disclose. We expect a stronger effect of refinancing risk in both cases, that is, when firms are more exposed to refinancing risk and when they are less able to mitigate refinancing risk.

\section{Results}

\subsection{Descriptive Statistics}

We start by describing the variables for our main analysis. The sample that corresponds to our firm fixed effect specification consists of 17,188 observations from 2003 to 2016. In this sample, the likelihood of providing at least one capital expenditure forecast is $51 \%$, and the average number of capital expenditure forecasts is 1.63 per year (the measure takes zero for firm-year observations with no capital expenditure forecasts). The likelihood of providing at least one earnings forecast is $49 \%$, and the average number of earnings forecasts is 3.53. Despite the similarity in the unconditional likelihood of issuing a capital expenditure forecast and an earnings forecast, the number of earnings forecasts in a year is higher than that of capital expenditure forecasts because earnings forecasts can be either quarterly or annual whereas capital expenditure forecasts are mainly annual. Overall, the descriptive statistics suggest that capital expenditure forecasts represent non-trivial portion of firms' total forecasting activity.

[Insert Table 1]

The average amount of long-term debt due within the next year as a percentage of total debt 
is $8.7 \%$ with standard deviation $16.1 \%$, which suggests a large amount of cross-sectional variation. The distribution of refinancing risk is skewed. The median firm-year observation only has $2.5 \%$ of total debt due in the next year. These firms presumably have very low refinancing risk. The 75 th percentile firm-year observation has $10 \%$ of total debt due in the next year. We also notice large cross-sectional variations in the control variables. All continuous variables are winsorized at $1 \%$ and $99 \%$ to mitigate outlier concerns.

We next examine the relation between refinancing risk and other variables in our sample. To present the relation between capital expenditure forecasts and refinancing risk, we plot in Figure 1 the relation between refinancing risk and the frequency of capital expenditure forecasts. We first sort refinancing risk into deciles, which are presented in the horizontal axis, and then compute the average number of capital expenditure forecasts across firm-year observations for each decile, which is presented in the vertical axis.

Figure 1 provides descriptive evidence consistent with H1 that higher refinancing risk is associated with fewer disclosures of capital expenditure forecasts. When refinancing risk is low (below median), the relation between refinancing risk and the frequency of capital expenditure forecasts is almost flat. This pattern echoes the distribution of refinancing risk shown in Table 1. Because the median firm is presumably not subject to refinancing risk (the amount of debt due next year as a percentage of total debt for the median firm is only $2.5 \%$ ), we do not expect a relation between refinancing risk and disclosures when refinancing risk is below the median. As refinancing risk increases, the frequency of capital expenditure forecasts starts to decline.

\section{[Insert Figure 1]}

Table 2 describes the relation between refinancing risk, sorted into deciles, and the mean of the control variables. Because many firms have almost zero percentage of debt due in the next year, the first two deciles are combined into a single group. Larger firms tend to have lower refinancing risk. Firm performance and refinancing risk exhibit weak nonlinear relations. Firm-year observations that have worse ROA and lower stock returns and suffer from loss tend to belong to the the first two deciles and the top decile of refinancing risk. The relation between return volatility and refinancing risk is almost flat for the first nine deciles of refinancing risk. Firm-year observations belonging to the top decile of refinancing risk have higher return volatility. In terms of leverage, 
firms with higher refinancing risk tend to have higher leverage. This relation exists despite that we scale the long-term debt due in the next year with total debt when computing refinancing risk, which mechanically introduces a negative relation between leverage and refinancing risk. Higher refinancing risk is associated with lower institutional ownership and analyst following. Finally, higher refinancing risk is associated with lower debt issued in the next year, consistent with the negative effect of refinancing risk on obtaining financing.

\section{[Insert Table 2]}

Because capital expenditure forecasts are likely to be driven by industry-level investment practices, we next examine the distribution of the number of capital expenditure forecasts and earnings forecasts for each one-digit SIC industry in our sample. The results are presented in Table 3.

Table 3 shows that firms' capital expenditure forecasts and earnings forecasts do not exhibit the same across-industry variation. Firms in mining and construction industries $(\mathrm{SIC}=1)$ on average issue more capital expenditure forecasts (2.5 per firm-year) and fewer earnings forecasts (1.4 per firm-year) than other industries. Agricultural and public administration industries (SIC $=0$ and $\mathrm{SIC}=9$ ) have the opposite patterns. Firms in these two industries issue 0.8 and 0.4 capital expenditure forecasts per firm-year, which is less frequent than firms in the other industries. Firms in these two industries respectively issue 4.9 and 4.5 earnings forecasts, more frequently than firms in the other industries. The distinctions between earnings forecasts and capital expenditure forecasts suggest that the same factors that drive earnings forecast decisions may not affect capital expenditure forecast decisions.

Table 3 also demonstrates that Industries differ in their refinancing risk. Firms in mining and construction industries have lower refinancing risk relative to those in public administrations. The results suggest that a relation between refinancing risk and capital expenditure forecasts might be driven by across-industry heterogeneity. We therefore control for industry-fixed effects in our empirical specifications. In most of the empirical specifications, we control firm fixed effects, which subsume the industry fixed effects.

[Insert Table 3] 


\subsection{Main results}

This section examines the relation between refinancing risk and the disclosure of capital expenditure forecasts. Our main prediction is that firms facing higher refinancing risk reduce the disclosure of capital expenditure forecasts. We examine both the existence and frequency of capital expenditure forecasts.

\section{[Insert Table 4]}

Table 4 presents our main results. Column (1) and (2) report our main specification in (1) using the existence of capital expenditure forecasts as the dependent variable. Column (1) controls for two-digit SIC industry fixed effects. Column (2) controls for firm fixed effects. Column (3) and (4) report our main specification of (1) using the number of capital expenditure forecasts as our dependent variable. Column (3) controls for two-digit SIC industry fixed effects. Column (4) controls for firm fixed effects. All columns include control variables.

We find that higher refinancing risk is associated with lower likelihood of disclosing capital expenditure forecasts. We find similar results using the frequency of capital expenditure forecasts as the dependent variable. Using the coefficient estimate from Column (2), other things equal, an inter-quartile increase in refinancing risk is associated with a $2.25 \%$ decrease in the probability of issuing capital expenditure forecasts in the next year. Using the coefficient estimate from Column (4), an inter-quartile increase in refinancing risk is associated with a decrease in the number of capital expenditure forecasts by 1.2 .

Turning into the effects of the control variables, we find that firms with lower growth opportunities, that is, higher book-to-market ratio, are more likely to issue capital expenditure forecasts, consistent with lower proprietary cost for firms with lower growth opportunities. Similar to Guay et al. (2016) who examine the total number of management forecasts, we find no relation between return volatility and the likelihood and number of capital expenditure forecasts when not controlling for firm fixed effects, but a positive relation when controlling for firm fixed effects. To the extent that return volatility captures information asymmetry in the stock market, the results are consistent with firms having stronger incentive to disclose when the level of information asymmetry increases. Leverage is positively related to the issuance of capital expenditure forecasts. This confirms results from prior studies that firm investment and leverage are related (Lang et al., 
1996). Similar to the literature on earnings forecasts, both analyst following and percentage of institutional ownership are positively related to the likelihood and number of capital expenditure forecasts (Ajinkya et al., 2005).

We do not find a significant relation between other control variables and the likelihood or number of capital expenditure forecasts. In particular, changes in the amount of long-term debt issuance are not significantly related to capital expenditure forecasts. The result suggest maturity management, which is associated with changes in long-term debt, does not drive the decision to issue capital expenditure forecasts. Interestingly, firm performance, measured by earnings (ROA), does not seem to be related to firms' decisions to issue capital expenditure forecasts. This result is consistent with the evidence provided by Lu and Tucker (2012) who also document an insignificant relation between firm performance and capital expenditure forecasts for their main sample. Park et al. (2018) who examines whether firms disclose information to attract investors' attention also find similar results. The result suggests that capital expenditure forecasts are issued to inform investors of firms' future investment, which are long-run focused and are less likely to be affected by short-run performance. This result provides preliminary evidence that our results are less likely to hold for current-year earnings forecasts, which are related to short-run performance.

Overall, the results from Table 4 confirm $\mathrm{H} 1$ that higher refinancing risk is associated with fewer disclosures of capital expenditure forecasts. Because we include firm fixed effects, the effects are not driven by time invariant unobserved firm heterogeneity. Our control variables capture determinants of maturity choices based on findings from prior studies. In particular, maturity management does not seem to drive our results. The results are consistent with management hiding bad news about investment from shareholders when refinancing risk is high. As discussed in section 2, finding a negative relation between refinancing risk and is inconsistent with the alternative mechanism that firms facing higher refinancing risk increase disclosure to gain access to the public bond or equity market or to increase the credibility of their communications with lenders (e.g., Frankel et al., 1995; Sengupta, 1998). We caution that our findings do not dispute studies that document that firms increase disclosures when seeking public financing. Our evidence implies that our measure of refinancing risk mainly captures private debt refinancing presumably with banks, an interpretation that is shared by prior studies (e.g., Harford et al., 2014). 


\subsubsection{Alternative explanations}

An alternative explanation for the results in Table 4 was that lenders increase monitoring in periods of credit rollover, which in turn changes firms' disclosure incentives. As discussed in section 2, in contrast with $\mathrm{H} 1$ that mainly applies to capital expenditure forecasts, the monitoring mechanism applies to both capital expenditure forecasts and earnings forecasts. We repeat the specification in equation (1) but replace the dependent variable with current year earnings forecasts.

Table 5 present the regression results. We do not find statistical evidence that indicates a lower likelihood of earnings forecasts when refinancing risk increases. The coefficient estimates are neither statistically nor economically significant. An inter-quartile increase in refinancing risk is associated with $0.23 \%$ lower likelihood of issuing an earnings forecast and with 0.003 fewer earnings forecasts. Recall that the effects on the likelihood and number capital expenditure forecasts are respectively $2.25 \%$ and 1.2 , which are an order of magnitude larger. If lender monitoring were to play a major role, we would have seen a decline in earnings forecasts. The result suggests that an increase in lender monitoring during periods of credit rollover does not drive the decrease in capital expenditure forecasts.

[Insert Table 5]

The analysis in Table 5 assumes that management can reduce earnings forecasts in the same magnitude as they do for capital expenditure forecasts. Empirically, it is possible that the provision of earnings forecast is stickier than that of capital expenditure forecast, so it is harder to management to stop providing earnings forecasts. Untabulated analysis suggests that, if anything, capital expenditure forecasts are stickier than earnings forecasts. We regress the provision of a capital expenditure forecast on whether there was a capital expenditure forecast in the previous year, controlling for firm and year fixed effects. The regression coefficient is 0.47. Similarly, we regress the provision of an earnings forecast on whether there was an earning forecast in the previous year, controlling for firm and year fixed effects. The regression coefficient is 0.30 . The same regressions controlling for only year fixed effects produce slope coefficients of 0.78 for capital expenditure forecasts and 0.77 for earnings forecasts. Overall, there is no evidence that it is harder not to provide earnings forecasts than not to provide capital expenditure forecasts. 
Another prediction from the monitoring mechanism is that the effect of lender monitoring on firm disclosures should vary with the existing level of shareholder monitoring. Lender monitoring should have a smaller effect when existing shareholders monitor more. We test this prediction by interacting refinancing risk with the level of institutional ownership. The interaction term should be significantly different from zero if refinancing risk mainly captures lender monitoring. We report our

analysis in Table 6. Contrary to the prediction based on lender monitoring, Table 6 demonstrates that the interaction term is not significantly different from zero.

[Insert Table 6]

\subsubsection{Additional analysis}

This section provides additional analyses to support our results. Our hypothesis argues that higher refinancing risk is associated with worse news about firm investment. If this is true, a higher level should be associated with a higher likelihood of failure to obtain financing or obtain financing with unfavorable terms, which predicts a lower level of investment. To test this, we regress investment, defined as total capital expenditure in year t scaled by assets in period t-1, on refinancing risk. We report our results in Table 9. We find that firms with higher refinancing risk have a statistically significant lower amount of capital expenditure in the following year.

[Insert Table 9]

\subsection{Cross-sectional variation in refinancing risk}

This section examines whether firms that are more exposed to refinancing risk and are less able to mitigate refinancing risk are more likely to reduce capital expenditure forecasts. We first investigate whether the negative relation between refinancing risk and disclosure is stronger for firms that are more exposed to refinancing risk. Table 7 reports the cross-sectional results on the proxies for exposure to refinancing risk: firm uncertainty, credit rating, and leverage. For each cross-sectional variable, we create a dummy variable that equals one when the exposure to refinancing risk is high.

[Insert Table 7] 
The results show that, when firms are more exposed to refinancing risk, they are more likely to reduce the likelihood of disclosing capital expenditure forecasts and the frequency of capital expenditure forecast disclosures. We find that other things equal, an inter-quartile increase in refinancing risk is associated with a reduction in the number of capital expenditure forecasts by 1.4 for periods of high ex-ante uncertainty compared to periods of less ex-ante uncertainty, proxied by volatility. In addition, an inter-quartile increase in refinancing risk is associated with a decrease of 1.7 capital expenditure forecasts for speculative-grade firms compared to non-speculative grade firms. similar to the prior two results, we find that an inter-quartile increase in refinancing risk is associated with a decrease of 1.4 capital expenditure forecasts for highly levered firms compared to less levered firms.

We next investigate whether the negative relation between refinancing risk and disclosure is stronger for firms that are less capable of mitigating refinancing risk. Table 8 reports the crosssectional results on the proxies for firms' capability of mitigating refinancing risk: firm profitability and cash holding. For each cross-sectional variable, we create a dummy variable that equals one when the capability of mitigating refinancing risk is high.

\section{[Insert Table 8]}

The results show that, when firms have greater capability to mitigate refinancing risk, they are less likely to reduce the disclosure of capital expenditure forecasts and the number of capital expenditure forecasts. In our sample, firms with lower profitability reduce capex forecasts by 2 , all else equal, for an inter-quartile increase in refinancing risk, compared to 1 during periods of high profitability. Similarly, firms with higher cash holdings reduce capital expenditure forecasts by .8 compared to a reduction of -1.85 during periods of low cash holdings.

Overall, the cross-sectional evidence provides further support for a role of refinancing risk in driving firm capital expenditure forecasts. Omitted factors will have explain why refinancing risk is associated with a larger reduction in capital expenditure forecasts when firms are more exposed to refinancing risk and less able to mitigate refinancing risk. 


\subsection{Consequences}

The results so far suggest that management has incentives to withhold bad news about capital expenditures for capital market reasons. This section investigates two types of costs from reducing capital expenditure forecasts: (1) information asymmetry, and (2) management learning from the stock price.

\section{Conclusion}

A large literature examines how equity and public bond financing affects corporate information environments and corporate voluntary disclosure decisions. In contrast, the effects of debt financing on disclosure decisions are less understood. We examine the relation between refinancing risk and firms' decisions to issue capital expenditure forecasts. Refinancing risk represents periods of heightened uncertainty about the likelihood of being able to obtain financing and the terms of financing. Prior studies show that higher refinancing risk can reduce investment. Theories of strategic disclosure that predict that firms have incentive to withhold bad news from investors (Verrecchia, 1983; Dye, 1985; Jung and Kwon, 1988). Combining the two strands of literature, we predict a decrease in the voluntary disclosure of capital expenditure forecasts when firms face high refinancing risk.

Using an OLS specification to examine the relation between periods of high refinancing risk and voluntary disclosures of capital expenditure forecasts, we find that firms with higher refinancing risk have lower likelihood and frequency of capital expenditure forecasts. Other things equal, an inter-quartile increase in refinancing risk is associated with $2.25 \%$ lower likelihood of issuing capital expenditure forecasts in a year, and a decrease in the number of capital expenditure forecasts by -1.2 .

We also examine the relation between refinancing risk and voluntary disclosure of capital expenditure forecasts in two sets of cross-sectional tests. If the relation between refinancing risk and voluntary disclosure is caused by an increase in uncertainty regarding the investment ability of firms in the future, then we expect the relation to strengthen when the firm is exposed to more refinancing risk. To test this, we examine periods of high ex-ante uncertainty, high leverage, and low credit rating. In addition, we expect the relation between refinancing risk and capital expenditure 
forecasts to be mitigated when the firm has greater ability to mitigate refinancing risk. To test this, we examine the relation between refinancing risk and disclosure when firms have higher cash holdings and high profitability. We find that the negative relation between refinancing risk and disclosure of capital expenditure forecasts is stronger when firms are more exposed to refinancing risk and are less able to mitigate refinancing risk. The evidence supports our prediction that higher refinancing risk reduces the issuance of capital expenditure forecasts.

Our findings suggest that firms' information environment is multi-faceted. While prior studies have focused on earnings related forecasts, other types of disclosures become increasingly common. Our paper documents that factors that drive firms' decisions to issue other types of forecasts can potentially differ from those driving earnings forecasts, which open up possibilities for more future research. 


\section{References}

Ajinkya, B., S. Bhojraj, and P. Sengupta (2005). The association between outside directors, institutional investors and the properties of management earnings forecasts. Journal of Accounting Research 43(3), $343-376$.

Ali, A., Z. Fan, and N. Li (2018). The role of capital expenditure forecasts in debt contracting. Working paper, University of Texas at Dallas.

Almeida, H., M. Campello, and B. Laranjeira (2012). Corporate Debt Maturity and the Real Effects of the 2007 Credit Crisis. Critical Finance Review (1), 3-58.

Anilowski, C., M. Feng, and D. J. Skinner (2007). Does earnings guidance affect market returns? The nature and information content of aggregate earnings guidance. Journal of Accounting and Economics 44(1-2), $36-63$.

Bae, J., G. C. Biddle, and C. W. Park (2017). Voluntary capex guidance, analyst feedback and capital investment efficiency. Working paper.

Barclay, M. J. and C. W. Smith (1995). The maturity structure of corporate debt. the Journal of Finance 50(2), 609-631.

Beyer, A., D. A. Cohen, T. Z. Lys, and B. R. Walther (2010). The financial reporting environment: Review of the recent literature. Journal of Accounting and Economics 50(2-3), 296-343.

Billett, M. T., T.-H. D. KING, and D. C. Mauer (2007). Growth opportunities and the choice of leverage, debt maturity, and covenants. The Journal of Finance 62(2), 697-730.

Bushee, B. J. and C. F. Noe (2000). Corporate disclosure practices, institutional investors, and stock return volatility. Journal of Accounting Research 38(2000), 171-202.

Chen, Q. and R. Vashishtha (2017). The effects of bank mergers on corporate information disclosure. Journal of Accounting and Economics 64(1), 55-67.

Chen, S., D. Matsumoto, and S. Rajgopal (2011). Is silence golden? An empirical analysis of firms that stop giving quarterly earnings guidance. Journal of Accounting and Economics 51(1-2), 134-150.

Diamond, D. W. (1991). Debt maturity structure and liquidity risk. The Quarterly Journal of Economics 106(3), 709-737. 
Diamond, D. W. (1993). Seniority and maturity of debt contracts. Journal of Financial Economics 33(3), $341-368$.

Dye, R. A. (1985). Disclosure of nonproprietary information. Journal of Accounting Research 23(1), 123-145.

Frankel, R., M. McNichols, and G. P. Wilson (1995). Discretionary disclosure and external financing. The Accounting Review, 135-150.

Froot, K. A., D. S. Scharfstein, and J. C. Stein (1993). Risk management: Coordinating corporate investment and financing policies. The Journal of Finance 48(5), 1629-1658.

Gopalan, R., F. Song, and V. Yerramilli (2014). Debt Maturity Structure and Credit Quality. Journal of Financial and Quantitative Analysis (49), 817-842.

Grossman, S. J. (1981). The informational role of warranties and private disclosure about product quality. The Journal of Law and Economics 24(3), 461-483.

Guay, W., D. Samuels, and D. Taylor (2016). Guiding through the fog: Financial statement complexity and voluntary disclosure. Journal of Accounting and Economics 62(2), 234-269.

Gul, F. A. and J. Goodwin (2010). Short-term debt maturity structures, credit ratings, and the pricing of audit services. The Accounting Review 85(3), 877-909.

Han, J. C. and J. J. Wild (1991). Stock price behavior associated with managers' earnings and revenue forecasts. Journal of Accounting Research 29(1), 79-95.

Harford, J., S. Klasa, and W. F. Maxwell (2014). Refinancing risk and cash holdings. The Journal of Finance 69(3), 975-1012.

He, Z. and W. Xiong (2012). Rollover risk and credit risk. The Journal of Finance 67(2), 391-430.

Healy, P. M., A. P. Hutton, and K. G. Palepu (1999). Stock performance and intermediation changes surrounding sustained increases in disclosure. Contemporary Accounting Research 16(3), 485-520.

Hirst, D. E., L. Koonce, and S. Venkataraman (2008). Management earnings forecasts: A review and framework. Accounting Horizons 22(3), 315-338.

Houston, J. F., B. Lev, and J. W. Tucker (2010). To guide or not to guide? Causes and consequences of stopping quarterly earnings guidance. Contemporary Accounting Research 27(1), 143-185.

Hutton, A. P., G. S. Miller, and D. J. Skinner (2003). The role of supplementary statements with management earnings forecasts. Journal of Accounting Research 41(5), 867-890. 
Jung, W.-O. and Y. Kwon (1988). Disclosure when the market is unsure of information endowment of managers. Journal of Accounting Research 26(1), 146-153.

Kim, J. B., P. Shroff, D. Vyas, and R. Wittenberg-Moerman (2018). Credit default swaps and managers voluntary disclosure. Journal of Accounting Research 56(3), 953-988.

Lang, L., E. Ofek, and R. Stulz (1996). Leverage, investment, and firm growth. Journal of Financial Economics 40(1), 3-29.

Lang, M. and R. Lundholm (2000). Voluntary disclosure and equity offerings: Reducing information asymmetry or hyping the stock? Contemporary Accounting Research 17.

Lo, A. (2014). Do declines in bank health affect borrowers voluntary disclosures? evidence from international propagation of banking shocks. Journal of Accounting Research 47(4), 541-581.

Lu, H.-Y. and J. W. Tucker (2012). Nonearnings corporate guidance. Financial Management 41(4), $947-977$.

Lummer, S. L. and J. J. McConnell (1989). Further evidence on the bank lending process and the capitalmarket response to bank loan agreements. Journal of Financial Economics 25(1), 99-122.

Milgrom, P. R. (1981). Good news and bad news: Representation theorems and applications. The Bell Journal of Economics, 380-391.

Nagar, V., D. Nanda, and P. Wysocki (2003). Discretionary disclosure and stock-based incentives. Journal of Accounting and Economics 34(1-3), 283-309.

Opler, T. C. and S. Titman (1994). Financial distress and corporate performance. The Journal of Finance 49(3), 1015-1040.

Park, S., C. Schrand, and F. Zhou (2018). Management forecasts in crowded markets. Working paper, The Wharton School, University of Pennsylvania.

Rajan, R. G. (1992). Insiders and outsiders: The choice between informed and arm's-length debt. The Journal of Finance 47(4), 1367-1400.

Rauh, J. D. (2006). Investment and financing constraints: Evidence from the funding of corporate pension plans. The Journal of Finance 61(1), 33-71.

Sengupta, P. (1998). Corporate disclosure quality and the cost of debt. The Accounting Review 73(4), $459-474$. 
Stiglitz, J. E. and A. Weiss (1981). Credit rationing in markets with imperfect information. The American Economic Review 71(3), 393-410.

Vashishtha, R. (2014). The role of bank monitoring in borrowers discretionary disclosure: Evidence from covenant violations. Journal of Accounting and Economics 57(2), 176-195.

Verrecchia, R. E. (1983). Discretionary disclosure. Journal of Accounting and Economics 5, 179-194.

Wasley, C. E. and J. S. Wu (2006). Why do managers voluntarily issue cash flow forecasts? Journal of Accounting Research 44(2), 389-429.

Williamson, S. D. (1987). Costly monitoring, loan contracts, and equilibrium credit rationing. The Quarterly Journal of Economics 102(1), 135-145.

Xu, Q. (2017). Kicking maturity down the road: Early refinancing and maturity management in the corporate bond market. The Review of Financial Studies forthcoming. 


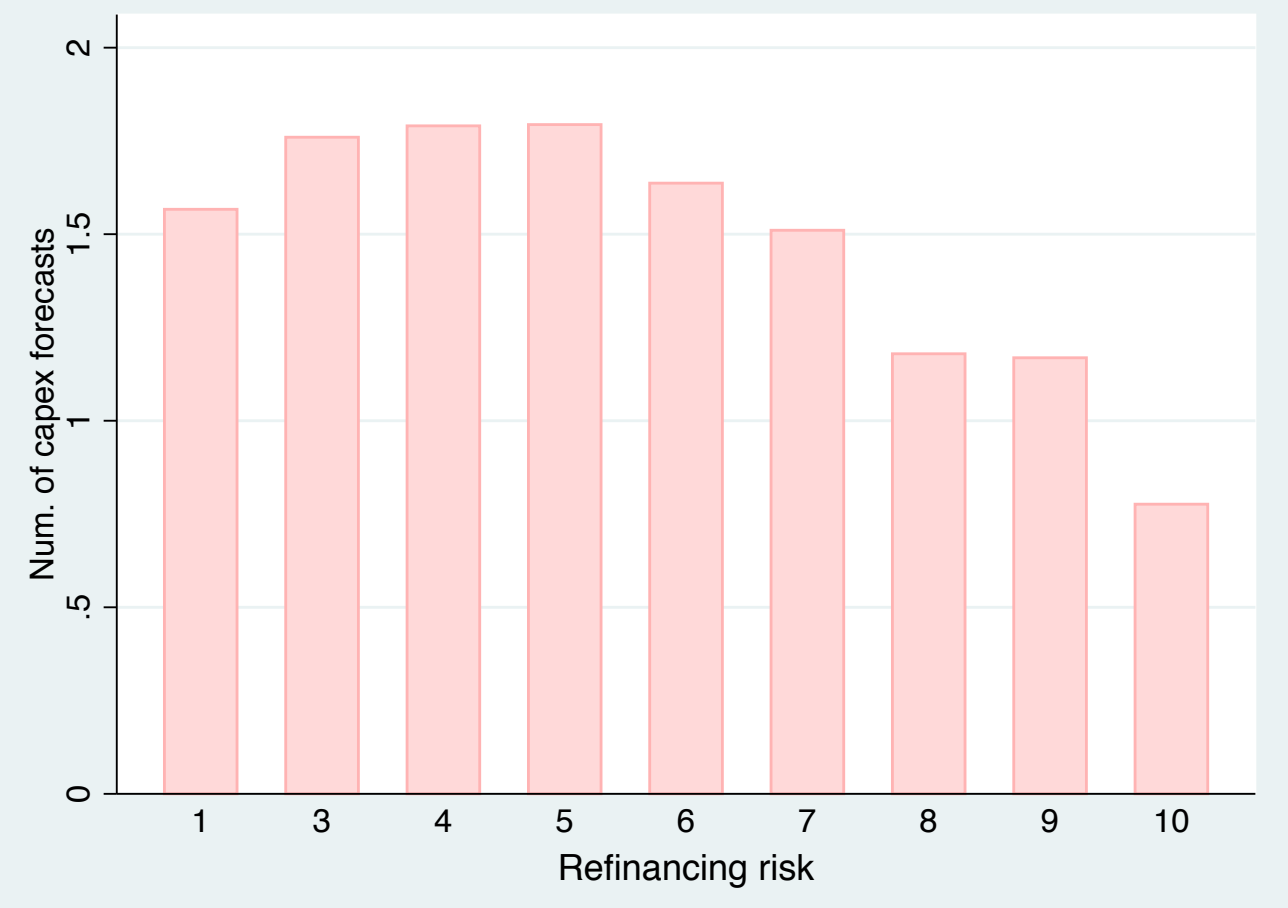

Figure 1: Refinancing risk and capital expenditure forecasts 
Table 1: Descriptive Statistics

This table presents descriptive statistics for the variables used in the empirical analysis. All variables are defined in Table A1.

\begin{tabular}{|c|c|c|c|c|c|c|}
\hline VARIABLES & $\mathrm{N}$ & Mean & Std & $25 \%$ & $50 \%$ & $75 \%$ \\
\hline RefRisk & 17188 & 0.087 & 0.161 & 0.001 & 0.025 & 0.103 \\
\hline Capex Guide & 17188 & 0.507 & 0.500 & 0.000 & 1.000 & 1.000 \\
\hline Earnings Guide & 17188 & 0.485 & 0.500 & 0.000 & 0.000 & 1.000 \\
\hline Num of Capex & 17188 & 1.630 & 2.066 & 0.000 & 1.000 & 3.000 \\
\hline Num of Earnings & 17188 & 3.528 & 4.983 & 0.000 & 0.000 & 6.000 \\
\hline $\log ($ Size $)$ & 17188 & 6.981 & 1.960 & 5.671 & 6.990 & 8.290 \\
\hline $\mathrm{ROA}$ & 17188 & -0.004 & 0.165 & -0.009 & 0.036 & 0.070 \\
\hline BTM & 17188 & 0.748 & 0.309 & 0.539 & 0.723 & 0.915 \\
\hline Adj Returns & 17188 & 0.031 & 0.412 & -0.249 & -0.018 & 0.231 \\
\hline Volatility & 17188 & 0.030 & 0.017 & 0.018 & 0.025 & 0.036 \\
\hline Leverage & 17188 & 0.341 & 0.193 & 0.202 & 0.294 & 0.427 \\
\hline Inst Own & 17188 & 0.538 & 0.519 & 0.000 & 0.558 & 0.876 \\
\hline Num Analysts & 17188 & 11.921 & 9.759 & 4.000 & 9.000 & 18.000 \\
\hline Loss & 17188 & 0.280 & 0.449 & 0.000 & 0.000 & 1.000 \\
\hline Amt Debt Issue & 17188 & 1.265 & 4.276 & 0.000 & 0.226 & 0.825 \\
\hline RefRisk & 17188 & 0.087 & 0.161 & 0.001 & 0.025 & 0.103 \\
\hline
\end{tabular}




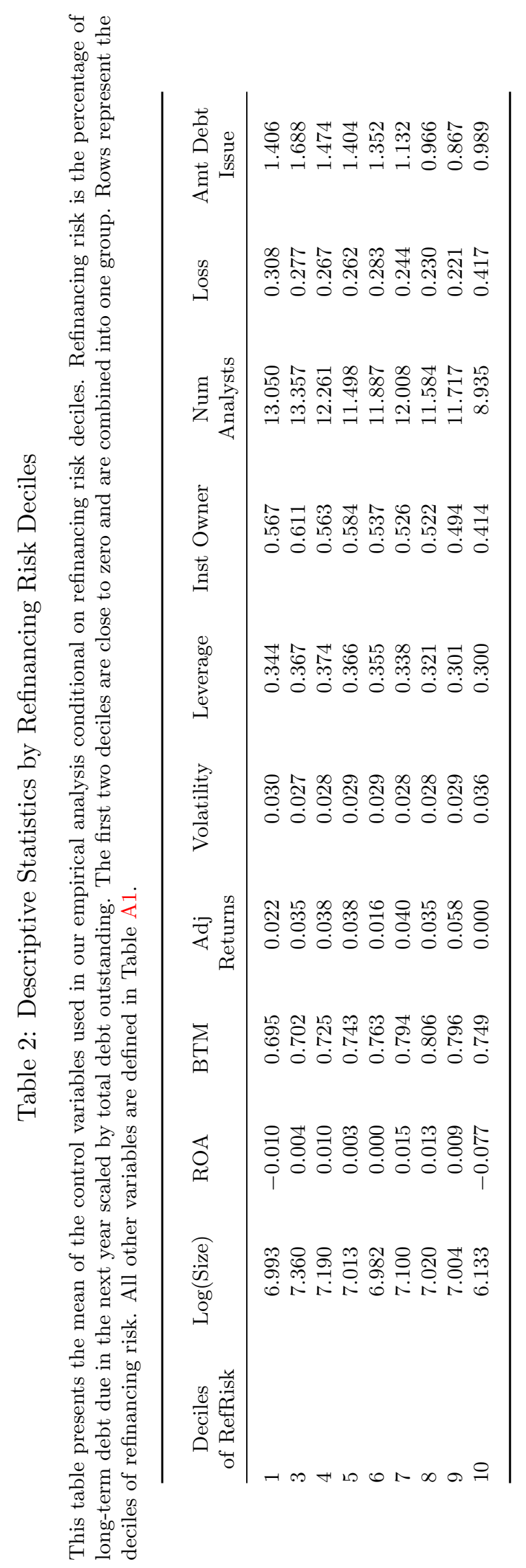


Table 3: Disclosure and Refinancing Risk by Industry

This table presents descriptive statistics for the disclosure variables and refinancing risk for each one-digit SIC industry. The disclosure variables include the issuance of capital expenditure forecasts (Capex Guide) and earnings forecasts Earnings Guide and the number of capital expenditure forecasts (Num Capex) and earnings forecasts (Num Earnings). All variables are defined in Table A1.

\begin{tabular}{cccccc}
\hline SIC & Capex Guide & Earnings Guide & Num Capex & Num Earnings & RefRisk \\
\hline 0 & 0.343 & 0.522 & 0.776 & 4.910 & 0.085 \\
1 & 0.633 & 0.253 & 2.542 & 1.440 & 0.068 \\
2 & 0.503 & 0.508 & 1.530 & 3.888 & 0.089 \\
3 & 0.454 & 0.553 & 1.341 & 4.074 & 0.102 \\
4 & 0.500 & 0.362 & 1.699 & 2.137 & 0.085 \\
5 & 0.560 & 0.581 & 1.747 & 4.528 & 0.066 \\
9 & 0.200 & 0.517 & 0.417 & 4.617 & 0.122 \\
\hline
\end{tabular}


Table 4: Main Test - Refinancing Risk and Capital Expenditure Forecasts

This table reports the coefficients of the OLS regression of management capital expenditure forecasts on refinancing risk in the following specification:

$$
\text { Capex } \text { Guide }_{i t+1}=\beta_{0}+\beta_{1} \operatorname{RefRisk}_{i t}+\beta_{2} X_{i t}+\epsilon_{i t},
$$

In columns (1) and (2), the dependent variable is the indicator for issuing a capital expenditure forecast in the year $\mathrm{t}+1$. In columns (3) and (4), the dependent variable is the number of capital expenditure forecasts issued in year $\mathrm{t}+1$. Column (1) and (3) uses industry fixed effects and Column (2) and (4) uses firm fixed effects. All the independent variables are lagged by one year and decile-ranked. Refinancing Risk is calculated as the portion of long-term debt due in year $t+1$, obtained from a firm's financial statements in year $t$. All control variables are defined in Table A1. $p$ values, reported in brackets, are based on standard errors clustered at the firm level. ***, **, and * denote statistical significance at the $1 \%, 5 \%$, and $10 \%$ level, respectively. Within $R^{2}$ is reported for fixed effect regressions.

\begin{tabular}{|c|c|c|c|c|}
\hline VARIABLES & Capex Guide & $\begin{array}{c}(2) \\
\text { Capex Guide }\end{array}$ & $\begin{array}{c}(3) \\
\text { Num. Capex }\end{array}$ & $\begin{array}{c}(4) \\
\text { Num. Capex }\end{array}$ \\
\hline RefRisk & $\begin{array}{c}-0.144^{* * *} \\
(0.019)\end{array}$ & $\begin{array}{c}-0.045^{* * *} \\
(0.015)\end{array}$ & $\begin{array}{c}-0.531^{* * *} \\
(0.080)\end{array}$ & $\begin{array}{c}-0.228^{* * *} \\
(0.059)\end{array}$ \\
\hline $\log ($ Size $)$ & $\begin{array}{l}0.229^{* * *} \\
(0.043)\end{array}$ & $\begin{array}{l}0.340^{* * *} \\
(0.046)\end{array}$ & $\begin{array}{l}0.998^{* * *} \\
(0.184)\end{array}$ & $\begin{array}{l}1.407^{* * *} \\
(0.195)\end{array}$ \\
\hline $\mathrm{ROA}$ & $\begin{array}{c}0.025 \\
(0.029)\end{array}$ & $\begin{array}{c}0.019 \\
(0.021)\end{array}$ & $\begin{array}{c}0.014 \\
(0.124)\end{array}$ & $\begin{array}{c}0.109 \\
(0.087)\end{array}$ \\
\hline BTM & $\begin{array}{l}0.084^{* * *} \\
(0.024)\end{array}$ & $\begin{array}{c}0.045^{*} \\
(0.024)\end{array}$ & $\begin{array}{l}0.348^{* * *} \\
(0.101)\end{array}$ & $\begin{array}{l}0.230^{* *} \\
(0.109)\end{array}$ \\
\hline Adj Returns & $\begin{array}{c}-0.002 \\
(0.011)\end{array}$ & $\begin{array}{c}0.009 \\
(0.009)\end{array}$ & $\begin{array}{c}0.034 \\
(0.045)\end{array}$ & $\begin{array}{c}0.050 \\
(0.037)\end{array}$ \\
\hline Volatility & $\begin{array}{c}0.008 \\
(0.025)\end{array}$ & $\begin{array}{l}0.041^{* *} \\
(0.020)\end{array}$ & $\begin{array}{l}0.262^{* *} \\
(0.111)\end{array}$ & $\begin{array}{l}0.300^{* * * *} \\
(0.082)\end{array}$ \\
\hline Leverage & $\begin{array}{l}0.049^{* *} \\
(0.021)\end{array}$ & $\begin{array}{l}0.052^{* *} \\
(0.020)\end{array}$ & $\begin{array}{c}0.138 \\
(0.094)\end{array}$ & $\begin{array}{l}0.259^{* * * *} \\
(0.083)\end{array}$ \\
\hline Inst Own & $\begin{array}{l}0.139^{* * *} \\
(0.028)\end{array}$ & $\begin{array}{c}0.055^{*} \\
(0.031)\end{array}$ & $\begin{array}{l}0.543^{* * *} \\
(0.123)\end{array}$ & $\begin{array}{c}0.272^{*} \\
(0.146)\end{array}$ \\
\hline Num Analysts & $\begin{array}{l}0.247^{* * *} \\
(0.038)\end{array}$ & $\begin{array}{l}0.196^{* * *} \\
(0.037)\end{array}$ & $\begin{array}{l}0.962^{* * *} \\
(0.162)\end{array}$ & $\begin{array}{l}0.711^{* * *} \\
(0.152)\end{array}$ \\
\hline Loss & $\begin{array}{c}-0.047^{* * *} \\
(0.016)\end{array}$ & $\begin{array}{c}0.007 \\
(0.012)\end{array}$ & $\begin{array}{c}-0.217^{* * *} \\
(0.070)\end{array}$ & $\begin{array}{c}0.036 \\
(0.048)\end{array}$ \\
\hline Amt Debt Issue & $\begin{array}{c}0.024 \\
(0.016)\end{array}$ & $\begin{array}{c}-0.018 \\
(0.012)\end{array}$ & $\begin{array}{c}0.098 \\
(0.069)\end{array}$ & $\begin{array}{c}-0.012 \\
(0.049)\end{array}$ \\
\hline Year FE & Yes & Yes & Yes & Yes \\
\hline Industry FE & Yes & No & Yes & No \\
\hline Firm FE & No & Yes & No & Yes \\
\hline Observations & 17,092 & 17,188 & 17,092 & 17,188 \\
\hline$R^{2}$ & 0.022 & 0.022 & 0.022 & 0.022 \\
\hline
\end{tabular}




\section{Table 5: Refinancing Risk and Earnings Forecasts}

This table reports the coefficients of the OLS regression of management earnings forecasts on refinancing risk in the following specification:

$$
\text { Earnings } \text { Guide }_{i t+1}=\beta_{0}+\beta_{1} \text { RefRisk } k_{i t}+\beta_{2} X_{i t}+\epsilon_{i t},
$$

In columns (1), the dependent variable is the indicator for issuing an earnings expenditure forecast with horizon shorter than or equal to one year in the year $t+1$. In columns (2), the dependent variable is the number of earnings forecasts with horizon shorter than or equal to one year issued in year $t+1$. Both columns include firm fixed effects. All the independent variables are lagged by one year and decile-ranked. Refinancing Risk is calculated as the portion of long-term debt due in year $t+1$, obtained from a firm's financial statements in year $t$. All control variables are defined in Table A1. $p$ values, reported in parantheses, are based on standard errors clustered at the firm level. ***, **, and ${ }^{*}$ denote statistical significance at the $1 \%, 5 \%$, and $10 \%$ level, respectively. Within $R^{2}$ is reported for fixed effect regressions.

(1)

Earnings Guide

$\begin{array}{cc}-0.009 & -0.013 \\ (0.013) & (0.138) \\ 0.225^{* * *} & 3.431^{* * *} \\ (0.044) & (0.426) \\ 0.065^{* * *} & 0.660^{* * *} \\ (0.022) & (0.198) \\ 0.025 & 0.448^{* *} \\ (0.023) & (0.225) \\ 0.021^{* *} & 0.328^{* * *} \\ (0.009) & (0.080) \\ -0.113^{* * *} & -0.991^{* * *} \\ (0.020) & (0.188) \\ 0.017 & -0.219 \\ (0.019) & (0.202) \\ -0.013 & -0.149 \\ (0.032) & (0.320) \\ 0.136^{* * *} & 0.649^{* *} \\ (0.034) & (0.318) \\ -0.038^{* * *} & -0.051 \\ (0.012) & (0.110) \\ 0.011 & 0.047 \\ (0.012) & (0.117) \\ & \end{array}$

Year FE

Firm FE

Observations

Yes

Yes

Yes

Yes

17,188

0.032
(2) Num. Earnings
$R^{2}$

17,188

0.032

*** $\mathrm{p}<0.01,{ }^{* *} \mathrm{p}<0.05,{ }^{*} \mathrm{p}<0.1$ 


\section{Table 6: Falsification Test - Institutional ownership}

This table reports the coefficients of the OLS regression of management capital expenditure forecasts on refinancing risk in the following specification:

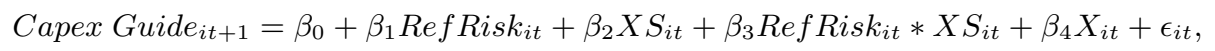

where $X S$ is an indicator that equals one when the capability of a firm to mitigate refinancing risk in year $t$ is high, and zero otherwise. In columns (1), the dependent variable is an indicator for issuing a capital expenditure forecast in the year $t+1$. In columns (2), the dependent variable is the number of capital expenditure forecast. All columns include firm fixed effects. All the independent variables are lagged by one year and decile-ranked. Refinancing Risk is calculated as the portion of long-term debt due in year $t+1$, obtained from a firm's financial statements in year t. All control variables are defined in Table A1.XS is HighIO, which equals one when institutional ownership of a firm-year observation is larger than the full-sample median, and zero otherwise. $p$ values, reported in parentheses, are based on standard errors clustered at the firm level. ***, **, and * denote statistical significance at the $1 \%, 5 \%$, and $10 \%$ level, respectively. Within $R^{2}$ is reported for fixed effect regressions.

\begin{tabular}{lcc}
\hline & $(1)$ & $(2)$ \\
VARIABLES & Capex Guide & Num. Capex \\
\hline \multirow{2}{*}{ RefRisk } & -0.037 & $-0.239^{* *}$ \\
HighIO & $(0.026)$ & $(0.102)$ \\
& $-0.065^{* *}$ & $-0.221^{*}$ \\
HighIO*RefRisk & $(0.030)$ & $(0.122)$ \\
& -0.012 & 0.010 \\
Control Variables & $(0.031)$ & $(0.124)$ \\
Year FE & Yes & Yes \\
Firm FE & Yes & Yes \\
Observations & Yes & Yes \\
$R^{2}$ & 17,188 & 17,188 \\
& & 0.0218 \\
\hline
\end{tabular}

*** $\mathrm{p}<0.01, * * \mathrm{p}<0.05, * \mathrm{p}<0.1$ 
Table 7: Cross-Sectional Test - Exposure to Refinancing Risk

This table reports the coefficients of the OLS regression of management capital expenditure forecasts on refinancing risk in the following specification:

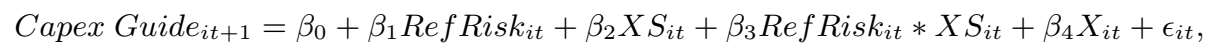

where $X S$ is an indicator that equals one when a firm-year is more exposed to refinancing risk, and zero otherwise. In columns (1), (3), and (5), the dependent variable is an indicator for issuing a capital expenditure forecast in the year $\mathrm{t}+1$. In columns (2), (4), and (6), the dependent variable is the number of capital expenditure forecast. All columns include firm fixed effects. All the independent variables are lagged by one year and decile-ranked. Refinancing Risk is calculated as the portion of long-term debt due in year $t+1$, obtained from a firm's financial statements in year $t$. All control variables are defined in Table A1. In columns (1) and (2), XS is HighLev, which equals one when the leverage of a firm-year observation is larger than the full-sample median, and zero otherwise. In columns (3) and (4), $X S$ is High Vol, which equals one when return volatility of a firm-year observation is larger than the full-sample median, and zero otherwise. In columns (5) and (6), XS is SpecGrade, which equals one when a firm is rated speculative grade in a year, and zero otherwise. $p$ values, reported in parantheses, are based on standard errors clustered at the firm level. ***, **, and ${ }^{*}$ denote statistical significance at the $1 \%, 5 \%$, and $10 \%$ level, respectively. Within $R^{2}$ is reported for fixed effect regressions.

\begin{tabular}{|c|c|c|c|c|c|c|}
\hline VARIABLES & Capex Guide & $\begin{array}{c}(2) \\
\text { Num. Capex }\end{array}$ & $\begin{array}{c}(3) \\
\text { Capex Guide }\end{array}$ & $\begin{array}{c}(4) \\
\text { Num. Capex }\end{array}$ & $\begin{array}{c}(5) \\
\text { Capex Guide }\end{array}$ & $\begin{array}{c}(6) \\
\text { Num. Capex }\end{array}$ \\
\hline RefRisk & $\begin{array}{c}-0.022 \\
(0.019)\end{array}$ & $\begin{array}{r}-0.130^{*} \\
(0.071)\end{array}$ & $\begin{array}{c}-0.012 \\
(0.019)\end{array}$ & $\begin{array}{c}-0.062 \\
(0.075)\end{array}$ & $\begin{array}{c}-0.001 \\
(0.026)\end{array}$ & $\begin{array}{c}-0.084 \\
(0.105)\end{array}$ \\
\hline HighLev & $\begin{array}{c}0.038^{* *} \\
(0.019)\end{array}$ & $\begin{array}{l}0.205^{* *} \\
(0.080)\end{array}$ & & & & \\
\hline RefRiskXHighlLev & $\begin{array}{c}-0.052^{* *} \\
(0.026)\end{array}$ & $\begin{array}{c}-0.226^{* *} \\
(0.105)\end{array}$ & & & & \\
\hline HighVol & & & $\begin{array}{l}0.059^{* * *} \\
(0.017)\end{array}$ & $\begin{array}{l}0.227^{* * *} \\
(0.071)\end{array}$ & & \\
\hline RefRiskXHighVol & & & $\begin{array}{c}-0.069^{* * *} \\
(0.025)\end{array}$ & $\begin{array}{c}-0.354^{* * *} \\
(0.096)\end{array}$ & & \\
\hline SpecGrade & & & & & $\begin{array}{l}0.080^{* * *} \\
(0.030)\end{array}$ & $\begin{array}{c}0.208 \\
(0.138)\end{array}$ \\
\hline RefRiskXSpecGrade & & & & & $\begin{array}{c}-0.125^{* * *} \\
(0.038)\end{array}$ & $\begin{array}{c}-0.350^{* *} \\
(0.158)\end{array}$ \\
\hline Control Variables & Yes & Yes & Yes & Yes & Yes & Yes \\
\hline Year FE & Yes & Yes & Yes & Yes & Yes & Yes \\
\hline Firm FE & Yes & Yes & Yes & Yes & Yes & Yes \\
\hline Observations & 17,188 & 17,188 & 17,188 & 17,188 & 9,343 & 9,343 \\
\hline$R^{2}$ & 0.025 & 0.025 & 0.026 & 0.026 & 0.023 & 0.023 \\
\hline
\end{tabular}

$* * * \mathrm{p}<0.01, * * \mathrm{p}<0.05, * \mathrm{p}<0.1$ 


\section{Table 8: Cross-Sectional Test - Mitigating Refinancing Risk}

This table reports the coefficients of the OLS regression of management capital expenditure forecasts on refinancing risk in the following specification:

$$
\text { Capex } \text { Guide }_{i t+1}=\beta_{0}+\beta_{1} \text { RefRisk }_{i t}+\beta_{2} X S_{i t}+\beta_{3} \operatorname{RefRisk}_{i t} * X S_{i t}+\beta_{4} X_{i t}+\epsilon_{i t}
$$

where $X S$ is an indicator that equals one when the capability of a firm to mitigate refinancing risk in year $t$ is high, and zero otherwise. In columns (1) and (3), the dependent variable is an indicator for issuing a capital expenditure forecast in the year $t+1$. In columns (2) and (4), the dependent variable is the number of capital expenditure forecast. All columns include firm fixed effects. All the independent variables are lagged by one year and decileranked. Refinancing Risk is calculated as the portion of long-term debt due in year $t+1$, obtained from a firm's financial statements in year $t$. All control variables are defined in Table A1. In columns (1) and (2), XS is HighCash, which equals one when the cash holding as a percentage of total asset of a firm-year observation is larger than the full-sample median, and zero otherwise. In columns (3) and (4), XS is HighROA, which equals one when ROA of a firm-year observation is larger than the full-sample median, and zero otherwise. $p$ values, reported in parantheses, are based on standard errors clustered at the firm level. ***, **, and * denote statistical significance at the $1 \%, 5 \%$, and $10 \%$ level, respectively. Within $R^{2}$ is reported for fixed effect regressions.

\begin{tabular}{|c|c|c|c|c|}
\hline VARIABLES & Capex Guide & $\begin{array}{c}(2) \\
\text { Num. Capex }\end{array}$ & $\begin{array}{c}(3) \\
\text { Capex Guide }\end{array}$ & $\begin{array}{c}(4) \\
\text { Num. Capex }\end{array}$ \\
\hline RefRisk & $\begin{array}{c}-0.099 * * * \\
(0.032)\end{array}$ & $\begin{array}{c}-0.435^{* * *} \\
(0.137)\end{array}$ & $\begin{array}{c}-0.087^{* * *} \\
(0.024)\end{array}$ & $\begin{array}{c}-0.416^{* * *} \\
(0.094)\end{array}$ \\
\hline HighCash & $\begin{array}{c}-0.050^{* *} \\
(0.020)\end{array}$ & $\begin{array}{c}-0.208^{* *} \\
(0.094)\end{array}$ & & \\
\hline RefRiskXHighCash & $\begin{array}{l}0.067^{* *} \\
(0.033)\end{array}$ & $\begin{array}{r}0.250^{*} \\
(0.142)\end{array}$ & & \\
\hline HighROA & & & $\begin{array}{c}-0.046^{* *} \\
(0.023)\end{array}$ & $\begin{array}{r}-0.165^{*} \\
(0.093)\end{array}$ \\
\hline RefRiskXHighROA & & & $\begin{array}{c}0.057^{* *} \\
(0.026)\end{array}$ & $\begin{array}{l}0.251^{* *} \\
(0.101)\end{array}$ \\
\hline Control Variables & Yes & Yes & Yes & Yes \\
\hline Year FE & Yes & Yes & Yes & Yes \\
\hline Firm FE & Yes & Yes & Yes & Yes \\
\hline Observations & 17,188 & 17,188 & 17,188 & 17,188 \\
\hline$R^{2}$ & 0.025 & 0.025 & 0.022 & 0.022 \\
\hline
\end{tabular}




\section{Table 9: Measure Validation: Refinancing Risk and Future Investment}

This table reports the coefficients of the OLS regression of investment in period $t+1$ on refinancing risk in period $t$ in the following specification:

$$
\text { Investment }_{i t+1}=\beta_{0}+\beta_{1} \text { RefRisk }_{i t}+\beta_{2} X_{i t}+\epsilon_{i t}
$$

All the independent variables are measured in the year $t$ and are decile ranked. Refinancing Risk is calculated as the portion of long-term debt due within the next year. Investment is calculated as capital expenditure in the year $t+1$ scaled by the book value of total assets in the year $t$. All variables are defined in Table A1. p-values, reported in brackets, are based on standard errors clustered at the firm level. ***, **, and * denote statistical significance at the $1 \%, 5 \%$, and $10 \%$ level, respectively. Within $R^{2}$ is reported.

\begin{tabular}{|c|c|}
\hline VARIABLES & P(Capex Forecasts) \\
\hline RefRisk & $\begin{array}{c}-0.006^{* * *} \\
(-3.30)\end{array}$ \\
\hline $\log ($ Size $)$ & $\begin{array}{l}-0.007 \\
(-1.06)\end{array}$ \\
\hline $\mathrm{ROA}$ & $\begin{array}{c}0.014^{* * *} \\
(4.70)\end{array}$ \\
\hline BTM & $\begin{array}{c}-0.046^{* * *} \\
(-12.47)\end{array}$ \\
\hline Adjureturns & $\begin{array}{c}0.019 * * * \\
(13.82)\end{array}$ \\
\hline Daily Volatility & $\begin{array}{c}-0.013^{* * *} \\
(-4.65)\end{array}$ \\
\hline Leverage & $\begin{array}{c}-0.022^{* * *} \\
(-8.60)\end{array}$ \\
\hline InstownOwn & $\begin{array}{c}0.008^{* *} \\
(1.98)\end{array}$ \\
\hline Nanalyst & $\begin{array}{l}-0.002 \\
(-0.45)\end{array}$ \\
\hline Loss & $\begin{array}{l}-0.001 \\
(-0.75)\end{array}$ \\
\hline DebtIssued & $\begin{array}{c}0.007^{* * *} \\
(4.28)\end{array}$ \\
\hline Year FE & Yes \\
\hline Firm FE & Yes \\
\hline Observations & 18,787 \\
\hline R-squared & 0.722 \\
\hline
\end{tabular}

Robust t-statistics in parentheses

*** $\mathrm{p}<0.01, * * \mathrm{p}<0.05, * \mathrm{p}<0.1$ 
Table A1: Variable definitions

\begin{tabular}{|c|c|c|}
\hline Variable Name & Source & Description \\
\hline \multicolumn{3}{|l|}{ Dependent Variables } \\
\hline $\mathrm{P}($ Capex Forecast $)$ & $\begin{array}{l}\mathrm{I} / \mathrm{B} / \mathrm{E} / \mathrm{S} \\
\text { Compustat }\end{array}$ & $\begin{array}{l}\text { Indicator variable equal to } 1 \text { if the management issued a } \\
\text { capital expenditure forecast in the year } t+1 \text {. }\end{array}$ \\
\hline Num. of Capex Forecast & $\begin{array}{l}\mathrm{I} / \mathrm{B} / \mathrm{E} / \mathrm{S} \\
\text { Compustat }\end{array}$ & $\begin{array}{l}\text { Frequency of the number of capital expenditures forecasts } \\
\text { in the year } t+1 \text {. }\end{array}$ \\
\hline \multicolumn{3}{|l|}{ Independent Variables } \\
\hline RefRisk & Compustat & Portion of long-term debt due within the next year. \\
\hline $\log ($ Size $)$ & $\begin{array}{l}\text { Compustat, } \\
\text { CRSP }\end{array}$ & Natural log of the market value of equity of the firm. \\
\hline $\mathrm{ROA}$ & Compustat & $\begin{array}{l}\text { Income before Extraordinary Operations scaled by book } \\
\text { value of total assets. }\end{array}$ \\
\hline BTM & $\begin{array}{l}\text { Compustat, } \\
\text { CRSP }\end{array}$ & $\begin{array}{l}\text { Book-to-market ratio, computed as the book value of total } \\
\text { assets scaled by the sum of total liabilities and the market } \\
\text { value of equity. }\end{array}$ \\
\hline AdjReturns & CRSP & $\begin{array}{l}\text { Market-adjusted returns, calculated as the market-adjusted } \\
\text { buy and hold return over the year t. }\end{array}$ \\
\hline Volatility & CRSP & Standard deviation of daily returns over the year t. \\
\hline Leverage & Compustat & $\begin{array}{l}\text { The leverage ratio, calculated by total debt over book value } \\
\text { of total assets. }\end{array}$ \\
\hline InstownOwn & $\mathrm{I} / \mathrm{B} / \mathrm{E} / \mathrm{S}$ & Portion of total equity held by institutional investors. \\
\hline Nanalyst & $\mathrm{I} / \mathrm{B} / \mathrm{E} / \mathrm{S}$ & Number of analysts following the firm during year t. \\
\hline Loss & Compustat & $\begin{array}{l}\text { Equal to } 1 \text { if Income Before Extraordinary Items is negative } \\
\text { and } 0 \text { otherwise. }\end{array}$ \\
\hline DebtIssued & Compustat & $\begin{array}{l}\text { Equal to long-term debt issuance in year } t \text { scaled by long- } \\
\text { term debt in the year t- } 1 \text {. }\end{array}$ \\
\hline CashHoldInd & Compustat & $\begin{array}{l}\text { Equal to } 1 \text { if the cash holdings, defined as cash summed with } \\
\text { short-term investments scaled by book value of total assets, } \\
\text { is greater than the median cash holdings and } 0 \text { otherwise. }\end{array}$ \\
\hline SpecGrade & Compustat & $\begin{array}{l}\text { Equal to } 1 \text { if the } \mathrm{S} \& \mathrm{P} \text { credit long-term rating is } \mathrm{BB}+, \mathrm{BB} \text {, } \\
\mathrm{BB}-, \mathrm{B}+, \mathrm{B}, \mathrm{B}-, \text { or } \mathrm{CCC}+\text {, and } 0 \text { otherwise. }\end{array}$ \\
\hline
\end{tabular}

